\title{
Bill McKibben on the End of Nature and the Reconstruction of American Environmentalism
}

\section{Mark Luccarelli}

University of Oslo

\begin{abstract}
McKibben is an environmentalist, formerly a staff writer for the "New Yorker" and currently a writer and visiting scholar at Middlebury College in Vermont. He describes himself as a "rootless child of the suburbs" which might commonly be understood as the starting point of a life path that leads to what Lawrence Buell calls "the metropolitan dream." McKibben chose to alter his course, first by immersing himself in naturist literature and then by moving deep into the Adirondack Mountains of New York State. His widely read and somewhat controversial 1989 book, "The End of Nature", argues that the achievement of unprecedented technology mastery over the natural environment has made 'belief' in nature, in both its autonomy and sublimity - impossible. In this article, I argue that "The End of Nature" provided an opportunity during a period of personal doubt, astonishing technological change and growing skepticism about the possibilities of American (indeed modern western) life, to reflect on the value of nature writing - a reflexive response which requires McKibben to reconsider - and ultimately reaffirm - his commitment to the wilderness ethic and to the possibility of environmental reform. The work of reaffirmation is accomplished in a recent book, entitled, "Wandering Home" (2005); McKibben uses the occasion of a hike from the Green Mountains of Vermont, west across the Champlain Valley and Lake Champlain to his home in the Adirondack Mountains of New York State in order to juxtapose a number of different landscapes and narratives productive of his quest to bring nature and culture into stronger relation in part through a greater sense of regional identity.
\end{abstract}

Key Words: nature - public intellectual - naturism - environmentalism - McKibben - Thoreau - climate change - middle landscape - ecocentrism - region - Adirondacks - Vermont 
In 1989 Bill McKibben, then a journalist for The New Yorker captured the public imagination and drew considerably scholarly interest by publishing The End of Nature. The book was a primer on global warming and presented the thesis that the human power to alter the environment had reached the point that it vanquished 'nature' as we've understood it since the Enlightenment. It was his first book, very much the work of a mere twenty-seven year old, he tells us retrospectively. ${ }^{1}$ McKibben suggests that the chief virtue of the work was as an expression of a young man's "enthusiasm." I prefer "earnestness"; the book conveys the feeling that McKibben is fundamentally honest and determined. It's partly the result of the voice he assumes: that of a talented amateur, a citizen-journalist not a scientist, certainly not a policy expert, not even a nature writer making esoteric claims about the character of his own experience in the woods. McKibben aspires to be a public intellectual who bears comparison with such late- and post-Progressive Era figures as Lewis Mumford, Van Wyck Brooks and Thorstein Veblen who were among the first to take seriously the American public sphere created by the national magazines and journals of public opinion. McKibben writes as to present us with a difficulty - the problem of global warming; there's a bit of the investigative journalist who has discovered a "problem" but also that of intellectual who has thought deeply about it while endeavoring to put his analysis in terms the public should understand. He doesn't pander; he presents and reflects on the dimensions of environmental thinking, the critique of environmentalism and the contours of our present dilemma.

For McKibben, appreciation of 'nature' - that is the wild landscapes of North America, its woods, lakes and mountains - had provided a personal answer to the feeling that modern civilization had gone wrong, a culture, as he says in a later book "drowned out by the roar of thoughtless commerce, pointless ease"2: he and his wife had moved deep into the Adirondack Mountains of New York State, into the heart of the largest wilderness area east of the Mississippi River where they lived (and still live) a life within the forest and nearby a lake. ${ }^{3}$ But McKibben makes very little of his new life world in

1. McKibben, "The Emotional Core of The End of Nature," Organization \& Enviromment. Vol. 18, no. 2, 182-185. June 2005

2. McKibben, Wandering Home: a Walk across America's Most Hopeful Landscape (New York: Crown Publishers, 2005), 155.

3. The Adirondack Forest Preserve was created by the State of New York by legislation in 1892 and a provision that the park lands remain "forever wild" was included in New York's revised constitution adopted in 1895. About half of the land inside the park boundaries are privately owned making the park closer in design 
this book, leaving us with a reading experience very unlike that gleaned from Thoreau's Walden or Aldo Leopold's A Sand County Almanac where the authors construct for us an alternative life - however fleeting or temporary in Thoreau's case - and bring the reader into closer relation to the natural world both for its sake and in order to contemplate the failures of civilization. Thoreau takes on a life of monastic seclusion, adopts an "aesthetic of relinquishment" in favor of nature while despairing at the fate of his fellow citizens who lead lives of "quiet desperation."

What I am describing in Thoreau's work - variously conceived as pastoral, nature writing or 'naturism' has had a long-standing in American letters. In effect, The End of Nature, though a work of informed journalism rather than a piece of nature writing, per se, plays with this structure. McKibben readily admits that he shares the prosperous middle class life and economic interests of his readers: "Most of us have pensions and retirement accounts and certificates of deposit and plans for the future, all of them based on the world operating pretty much as it has always operated." ${ }^{4}$ Happiness is now interpreted in the context of consumer capitalism: ". . . the terrible truth is most of rather like ... acquiring more things . . . they make us happy. We like the easy life." 5 We share a common mode of thinking, McKibben argues - "that we should increase in numbers and especially, in material wealth." ${ }^{\circ}$ Thus McKibben rather effectively dissipates the reader's sense of inferiority, the sinking feeling that the nature writer or environmentalist is addressing us from a position of moral superiority. Of course, McKibben lets us know that as an environmentalist he is wrestling with these issues; he describes how he and his wife have reduced long automobile trips in favor of cycling and despite his "poor gardening skills" they are attempting to grow more of their own food. And he admits that they must "try very hard not to think about how much we'd like to have a baby." " With these self-deprecating and apparently confessional remarks, McKibben takes on the voice of the public-spirited citizen who lacks a special attachment to nature or outdoor activities. It's a useful rhetorical strategy, permitting him to raise a question which would be difficult if perhaps not quite unthinkable in naturist circles: perhaps the love of nature and of the wild has little environ-

to those of Great Britain than that of American national parks which exclude any permanent human inhabitation.

4. McKibben, The End of Nature (New York: Random House, 1989), 109.

5. Ibid, 172.

6. Ibid,

7. Ibid, 188. 
mental significance; perhaps it is nothing more than an expression of the desire to find personal happiness. Must we not distinguish, he asks, between nature appreciation for our own enjoyment and doing what's right for the environment by reducing the 'human footprint' on the biosphere?

Here we find the core of McKibben's doubt. American naturism has a long history; its central idea is, as Lawrence Buell puts it, to find in nature "a touchstone of value for the edification of one's culture." Ecocritics have argued that American nature writers from Thoreau onward began a process of revising what was meant by 'nature' by moving away from the pastoral's concern with innocence and idyllic retreat toward "ecocentrism" or an understanding of nature for its own sake. It meant the development of the capacity to see in nature an 'other' worthy of respect.

In the context of McKibben's work, what's most important is the assumption both by contemporary nature writers and many in the environmental movement that nature appreciation corresponds to scientific knowledge. Consequently it has been argued that naturism was not only compatible with environmentalism whether defined as conservation, preservation, or ecological sustainability, but that a thorough respect for the natural world was necessary to demonstrate the need for environmental policies; this respect owed as much to nature writing as it did to advances in science and scientific advocates of ecology. In effect, the argument goes culture (writing) and environment (ecology) are deeply intertwined. ${ }^{10}$

The End of Nature was a wake-up call to the cadre of writers, activists and intellectuals associated with environmentalism (and McKibben counts himself among them): not only have we witnessed a radical break with nature, but our (cultural) assumptions about nature have contributed to this break. In making this argument, McKibben anticipated the line of thinking advanced by a cross-disciplinary group of literary scholars, historians, and landscape scholars who published the important book Uncommon Ground: Rethinking the Human Place in Nature in 1995 under the editorship of William Cronon. ${ }^{11}$

8. "But environmentally sound is not the same as natural": Ibid., 209. It's worth quoting because he will reconsider this proposition in Wandering Home.

9. Lawrence Buell, The Environmental Imagination: Thoreau, Nature Writing, and the Formation of American Culture (Cambridge, Mass.: Harvard University Press, 1995), 52.

10. See Luccarelli, review of Conserving Words: How American Nature Writers Shaped the Environmental Movement by Daniel Philippon (Athens \& London: University of Georgia Press, 2004) Organization and Environment 19:2 (Fall 2006): 291-296.

11. Cronon, Uncommon Ground (New York: W.W. Norton, 1995). 
Unlike many of the scholars participating in the "uncommon ground" project, McKibben was less interested in joining in an attack conducted by 'social constructionists' against the idea of wilderness than in raising questions about the American tradition of naturism from the point of view of a participant in that tradition. What he shared with Cronon, et al was a conviction that the character of the threats confronting the global environment required reflection on a still prevalent $19^{\text {th }}$ century discourse of nature. In this connection, McKibben's title refers first and foremost to the end of the idea of nature as moral compass for human action: the end of nature means the death of "a certain set of human ideas about the world and our place in it"12 - one of which, the idea of nature as a cultural margin and moral compass, had its roots in the literary pastoral. In forecasting the 'end of nature', McKibben is speaking directly to a community of scholars and activists who have pushed for implementation of wilderness protection as an environmentalist project.

At the same time, McKibben is addressing the wider public's conception of nature - an understanding which had and has so penetrated the social world that it stands at the very heart of modernity itself. This idea is that nature makes no demands, is characterized by a steady-state, and is law-like and stable. Mathematically knowable nature was exploitable, and although the theoretical natural sciences and physics in particular have long since discarded this conception in favor of an often unpredictable, fragile and highly interconnected $\operatorname{cosmos}^{13}$, western industrial societies - in their economic and technological organization and in their applied practical sciences - have continued to rely on the older understanding of nature as predictable and therefore safely exploitable. It is precisely this Enlightenment-era conception of nature that McKibben tells us is threatened. We have hardly blinked an eye in accepting ever more intricate technological mastery of the natural world because it is tied to our increasing cultural and personal self-determination. From a technical perspective, a future archaeologist might well conclude that greatest achievement of western civilization's globalist phase was the creation of vast shipyards and super-sized cargo vessels - utilitarian landscapes and impressive transportation technologies - designed to produce and distribute enormous quantities of

\section{McKibben, End of Nature, 8 .}

13. In fact the discovery of the threat posed by global warming simply represents the most dramatic and recent of a series of discoveries (including the effects of plate tectonics, asteroid strikes and epidemic disease) that reveal the unpredictable and dramatically interconnected qualities of the biosphere. Nonetheless the development of climate modeling shows that scientific work often proceeds from a practical willingness to make predictions that now must account for human influences. 
goods. A environmental historian, on the other hand, might well argue that the distribution of goods was a merely the backdrop to a civilization given over to multiplying its range self-determining subjectivities while pushing every other form of life on the planet to the brink of extinction.

McKibben is right to see that climate change raises questions that challenge environmentalism to respond in a fundamentally different way then the responses called for by earlier threats to the environment. It differs, specifically, from the dangers of deforestation or chemical poisoning which were the issues on which American environmentalism was first built. ${ }^{14}$ These were local and temporary problems: a degradation of the functioning of natural ecosystems which had the capacity to recover. We live now with the possibility that the biosphere itsclf is in the process of being undermined, threatening the basis of life on the planet. Furthermore, the Intergovernmental Panel on Climate Change has recently concluded with a "very high confidence" ${ }^{15}$ that climate change is the result of anthropogenic greenhouse gas concentrations that have accumulated since 1750 . While human influence is unmistakable it is also clear that there are many complicating natural phenomena that make it almost impossible to isolate the human effect on climate. Changes in the atmosphere that can be traced to human activity, for instance, might well entail a 'snow ball effect' setting into motion a the release of naturally-occurring carbon dioxide which is currently frozen in the artic with severe consequences. The climate it turns out is predisposed toward instability, and this predisposition means that human activities are blown all out of proportion. It's like the human body balanced on the knife's edge between stability and weight gain. Only a few more calories a day starts a chain of events leading to obesity - an outcome all out of proportion to what may seem to be a few innocuous calories. The point is that even should the political forces that wish to contain the emission of green house gases succeed, we won't return to 'normality', i.e. to the common understanding of nature over the last 300 years an understanding that McKibben says is disappearing. In short, McKibben's

14. The first of two great books of American conservation - George Perkins Marsh, Man and Nature, ed. and introduction by David Lowenthal (Seattle: University of Washington Press, 2003; orig. pub., 1864) - was chiefly concerned with deforestation and helped to set off the first wave of American conservation; the second book - Rachel Carson, Silent Spring introduction by Linda Lear; afterword by Edward O. Wilson (Boston: Houghton Mifflin, 2002; orig. pub. 1962) - was instrumental in the movement against chemicals and other pollutants.

15. IPCC "Climate Change 2007: The Physical Science Basis," fourth assessment report on climate change, p. 3; http://www.ipcc.ch/SPM2feb07.pdf released February 1, 2007; assessed February 2, 2007. 
thesis that we can no longer believe in a highly stable, predictable 'nature' seems to have been bolstered by recent science. There can be no return to 'nature' as we had known it; global warming has become a permanent feature of our common life as far as western civilization is concerned.

I have already introduced the second meaning of the word 'nature' $\mathrm{McK}$ ibben works with: a marginal but morally significant space outside the bounds of the social world and now I'd like to say more about it. Because of the particularities of the Amcrican experience, this space became identified with the wilderness or the sublime landscape. It is this sense of a moral-aesthetic experience of the wild that has meant so much personally to McKibben. The doubt McKibben raises about nature as a wild self-defining sphere independent of humankind concerns its efficacy and its mythic significance: nature as revelation of the power of the cosmos. The most arresting section of The End of Nature addresses this question by re-telling an episode recounted by Thoreau in The Maine Woods.

Thoreau and his fellow travelers are fishing for trout at Murch Creek, twelve miles from the summit of Mt. Katathdin. After losing his hook, Thoreau's companions banish him from the small boat which they were using as a platform to catch the fish where he was employed keeping the fish that were being thrown ashore from slipping back into the river. This gives Thoreau an opportunity to observe the fish more closely:

While yet alive before their tints had faded, they glistened like the fairest flowers, the product of primitive rivers, and he [Thoreau] could hardly trust his senses, as he stood over them, that these jewels should have swam away in that Aboljacknagesic water for so long, so many dark ages - these bright fluvialite flowers, seen of Indians only, made beautiful, the Lord only knows why, to swim there!16

The trout seemed to Thoreau to be unreal - "he could hardly trust his senses" - in part because of their dreamlike beauty but also because they really are not there 'for' him - a man of advanced $19^{\text {th }}$ century civilization, nor is he there for them. They suggest rather "the fables of Proteus, and all those beautiful sea monsters,-how all of history ... put to a celestial [purpose], is mythology always." 17

16. Thoreau, quoted in McKibben, The End of Nature, 212-213.

17. Thoreau, The Maine Woods (Princeton, N.J.: Princeton University Press, 1970, 2004; orig. pub. 1864),

54. 
Thoreau begins with environment: the stream - Aboljacknagesic ${ }^{18}$ - is defined by its Amerindian name - which like most aboriginal names has the great virtues of geographic specificity and accuracy in representation. We know where we are. He proceeds by referencing a familiar representation of nature to his readers: he paints a picturesque landscape, one familiar enough if you have seen the works of Asher Brown and other members of the Hudson River School of painting. Three men fishing on a wild, rock-strewn stream, two of them balanced precariously in a boat over the rushing water, while the third observes partly obscured by a tree-lined shoreline. The familiar picturesque aesthetic comes in part from Thoreau's decision to refer to himself in the third person whereby he becomes (initially) an object of our gaze, a rhetorical choice enabled by a convenience of plot: his expulsion from the boat for lack of a hook. Yet this very act of expulsion and marginalization confers a moral sensibility on the narrator. After all, his position requires an act of relinquishment: Thoreau is not catching the fish hence he can really 'see' them. Thoreau then transforms this aesthetic moment, driving visual pleasure (of the picturesque) toward memory ... recovering a sense of the magical in creation and the marvelous in (our) origin. To say that the fantastic colors of the trout were seen by the (pre-historical) Amerindians only, remaining unknown through the many "dark ages" of human history, becomes a means of inverting the $19^{\text {th }}$ century assumption about the privilege conferred by historical consciousness and indeed by civilization itself. Thoreau invokes the ultimate irreducibility of life to endow nature with a wonder and significance beneath logos: The fish were after all "made beautiful, the Lord only knows why, to swim there." They are simply there in their loveliness without reason or rationale. Enjoying a moment of aesthetic ecstasy, he drives us, nonetheless, toward an intense longing for a beloved world which, of course, is piqued by a sensibility of loss - the loss of the real that comes with artifice, with civilization.

Invoking the indigenous is an important theme in Thoreau's work and in The Maine Woods in particular, a book which describes three journeys by canoe into the largely unsettled portions of interior Maine. These trips provided Thoreau with an opportunity to reflect on the landscapes he knew so well - the woods and fields of his native eastern Massachusetts - by putting them in relation to the Maine wilderness, a vast territory that while certainly not untouched by the hand of man had never known the plow or the shepherd. Seeking this 'original' nature is clear evidence of Thoreau's developing 
ecological awareness, his understanding that the natural world has a logic of its own often at odds with the human world and valuable in its own right. Ecocentrism may be defined as the "advocacy of nature for its own sake" but its philosophical import is a matter of some dispute. Many scholars have argued (against the grain of my own reading) that Thoreau anticipates the contemporary tendency to pose "ecocentricism" against the human world and human values that is against a perspective its critics call 'homocentrism'. For Max Oeschlaeger Thoreau's experience in Maine - and particularly his recollection of arriving at the top of Katahdin when Thoreau writes that he made the acquaintance of unadorned "Earth" composed of "Chaos and Old Night"20 - amounted to a "Paleolithic coming-to-consciousness" a return to the prehistoric and a flat rejection of industrial civilization. ${ }^{21}$

McKibben, by contrast, understands Thoreau's text, initially, in terms of classical humanism as a kind of pastoral that by retreating from culture to nature raises moral concerns. The central opposition in this reading is between nature and instrumental reason understood as the destructive force unleashed by capitalist civilization. ${ }^{22}$ McKibben's newly arrived at (i.e. at the time of the book's preparation in the 1980s) understanding of the capacity of technical reason to break nature's monopoly on creation imposes itself on his reading of The Maine Woods, requiring him to re-evaluate the significance of Thoreau's trout pulled out of the wild stream:

... through biotechnology we have already synthesized growth hormone for trout. Soon pulling them from the water will mean no more than pulling cars from an assembly line. We won't have to wonder why the Lord made them beautiful and put them there; we will have created them to increase protein supplies or fish-farm profits. If we want to make them pretty we may. Soon Thoreau will make no sense. And when that happens ... the end of nature will be final. The loss of memory will be the eternal loss of meaning. ${ }^{23}$

The unrelenting application of instrumental reason underlies a technological assault on nature that began with the industrial age ("cars pulled from the assembly line") and will end in a fourth industrial revolution hased on developing the capacity to assume nature's procreative powers. It's worth lingering

19. Buell, Environmental Imagination, 52 .

20. Thoreau, The Maine Woods, 92.

21. Oeschlaeger quoted in Buell, Environmental Imagination, 12.

22. In this respect McKibben is following along the lines of Leo Marx's (The Machine in the Garden, New York: Oxford, 1964, esp. 242-265) characterization of Thoreau's encounter with technology.

23. McKibben, End of Nature, 213, emphasis added. 
on this point for a moment, for this argument - apart from its philosophical reflection on the sad futility of conventional ( $19^{\text {th }}$ century derived) American naturism - must also be understood in the context of American cultural history. McKibben reminds us of the American preference for what Leo Marx calls the "middle landscape" which in both its popular and high cultural forms seemed to be rooted in the agrarian myth of American origins. In his own way, McKibben is questioning the viability of such a myth suggesting instead that environmental progress might require the acceptance of the mega-machine: "Perhaps it would be best for the planet if all lived not on kibuttzes or Jeffersonian farms, but crammed into a few huge cities like so many ants." 24

The comment is only partly ironic. Clearly McKibben would like to restore the search for a "middle landscape" (which would now mean a sustainable one) as well as to provide protection for preserves where Thoreau's wild trout could survive. But having earnestly reported the 'end of nature' he has cleared the ground from under naturism and becomes uncertain of how to proceed. He turns instead to a question of a culture: we have no more time for utopias, for seeking human happiness, he tells us; we need to take "a stab at something else" - perhaps he says something called "atopia" (191). Atopia is roughly equivalent to the new realism, a reaction to the disappointments of the last thirty years, in this case the failure of the environmental movement to make major headway. Atopia has taken on many applications since McKibben wrote his book in 1989; Bill Clinton's politics of triangulation was atopian; and environmental organizations became atopian when they attuned themselves to the language of the market. As the market drowns out the idea of the commons, radical environmentalism now takes the form of retreat to one or more variants of deep ecology which pretends that human society can return to primitive or agrarian forms. Yet neither the claim of atopian realists, nor the falling back from utopian hopes, has facilitated change. The conditions of American life are such that even the mildest forms of managerial environmentalism have failed to win over American politicians to the hope that global climate change can be lessened. In the wider world, the development of green technologies has failed to fundamentally alter the world's pattern of energy usage, indeed the spreading of high energy consumption to Asia has made the situation even worse. Clearly managerial environmentalism is faltering for lack of political support inside the United States specifically and within the western democracies more generally. One is forced to 
conclude that the grim-minded political realism that swept over the environmental movement in the 1980 s failed to produce concrete results.

The tide of pulling back from environmental commitments affected McKibben's career prospects; he lost his position at the New Yorker as that venerable institution underwent a popularization and commercialization designed to restore profitability. All this history - public and personal - is taken up in McKibben's book Wandering Home (2005) which addresses the question: how should we engage our own skepticism?

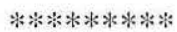

There's an interesting parallel between Wandering Home and "Chesuncook" the second of three narratives in The Maine Woods. There Thoreau reflects on the collapse of the first American republic - the wastage of the moral vision of the revolutionary generation in favor of the extension of slavery, the disappointment that was electoral democracy, the mania for extension of American territory and the beginnings of the systemic destruction of the American environment. Thoreau was involved in the political issues of his day, though he evidently prefers the natural landscape to the landscape of American politics. If the failure of the abolitionist and other social movements to change fundamentally American politics in the 1840s was the backdrop to The Maine Woods, the wastage of the great rebellion of the 1960s set the scene for Wandering Home. Like Thoreau, McKibben wants to return to the woods which is also a return to naturism - a return made more difficult by the critique he put forth in The End of Nature. In some ways Wandering Home suggests a response to the critique that he himself had helped to advance; in another respect the book is a retreat back to familiar ground. This has also much to do with the situating of McKibben's persona in the text as it reflects his own loss of status and his greater marginalization as suggested by the loss of his position at The New Yorker and by his self-deprecatory comments about his career: "I have the honorary title of 'scholar in residence' [at Middlebury College] which like most of my positions doesn't pay anything," comments that parallel those made by Thoreau who wrote in Walden: "I have now a library of nearly nine hundred volumes, over seven hundred of which I wrote myself" - i.e. the 700 unsold copies of A Week on the Concord and Merrimack Rivers. Loss of career prospects marks an ever increasing marginalization - a position which McKibben turns to his own uses. Engagement with that marginality prompts engagement with subjectivity and authorizes him to speak. He 
pretty effectively and at the same time reasonably engages this tradition of dissent.

Not surprisingly then Walking Home begins in a fog: "My mood was darker than it should have been for the start of a journey." ${ }^{25}$ It is a journey which at first glance has no greater significance than a personal one - "I've not been able to drag myself away from this small corner of the planet." ${ }^{26}$ The corner he's referring to is not merely obscure to the world at large; it's geographically nonsensical. He calls it a "region" but then has to admit that it consists of two very disparate areas geographically - both physically and culturally. Located on either side of Lake Champlain "the Verandacks" as he dubs this region of his imagination, consists of areas of very different character. To the east of the Lake lies the western half of the state of Vermont, part of New England he reminds us, and a "very tidy place." To the west lies the Adirondack Mountains of New York State. Geologically they are part of the Canadian Shield - a little piece of upland Canada stuck into the United States; they are the largest wilderness area east of the Rockies; culturally they are the real source of the American wilderness sublime; environmentally they've suffered from deforestation and plowing, from acid rain and the loss of open space to second homes. But they remain a vast rugged area of mountains, the largest wilderness west of the Rockies in the United States. The difference between these two areas, as McKibben see it lies in the fact that "New Englanders have learned a great deal, mostly through trial and error, about how to successfully inhabit a land" while "Adirondackers, often against their will, have learned as much about how to leave land alone." ${ }^{27}$ It from these two "casts of mind" - "real husbandry" and "real wilderness" that McKibben constructs his region.

That McKibben starts with Vermont and the attempt at "successful inhabitation" should not be surprising. It is directly related to the second question he is raising: "what constitutes the natural?" 28 To answer it we need to go back to the geo-environmental foundations of culture: human society is a part of nature and our fundamental relation to the natural world lies in how we use it. For McKibben nature in this sense is "real" by which he means the structure of material reality. In this connection he recollects that his interest in the nat-

25. McKibben, Walking Home, 9.

26. Ibid, 13.

27. Ibid, 17.

28. Ibid, 69 . 
ural world began when working on an article for the New Yorker in which he set out to describe where every pipe and wire in his apartment in Manhattan came from: "I followed the water pipes to the Catskill reservoirs, and traveled to Hudson Bay [Canada] to see the enormous dams producing power for Con Edison, and spent days on New York harbor with the giant garbage barges - and along the way had the sudden insight that the physical world actually mattered." 29 More than just the "props of politics and money," nature is the ground of the human world.

In Vermont McKibben weaves in and out of stories of small farmers and lumber cooperatives and entrepreneurs who are trying to blend ecological principles with making a living - trying less to make of Vermont a model for the rest of the country than to find strategies for survival. It's a struggle that now must be contained within the neo-liberal language of markets and niches or retreat to the safety of privileged institutional arrangements (like Middlebury College) - but it is also an attempt to build a middle landscape that reflects a sense of the pastoral - "real husbandry." The rural lies at the center of any credible environmental project, he suggests, and a meaningful rural way of life rests on the ability to make nature a conscious part of human design - in terms of technology, economy and society. Here McKibben must necessarily invoke the language of the middle landscape - inhabitation, community, landscape, place - with all the problems associated with those words: how can 'inhabitation' matter in a world that thrives on movement? What is community - if not another word for exclusion? What becomes of heterogeneity in a unified landscape? Unfortunately these questions can't be answered in terms of "true husbandry" in terms of the middle landscape. They require tackling issues of the urban world which in this book merely lurks in the shadows.

No wonder after all the practicalities of his book McKibben wanders home to the Adirondacks. In repossessing the wild he is reaffirming the American nature writing tradition, but this is only after he has adjusted it to eliminate its claims to absolute uniqueness and epistemological certainty. The cultural and technological contextualizations have stuck: there is no "pure wilderness" but this serves only to make the "relative wild" more valuable. Behind eco-centrism, beneath nature for its own sake remains "human reasons" for what we do. These might come to reflect a concern with stewardship and a cooperative vision of living with nature, as much as with the sense that wild nature is the source of enduring values. 